\title{
Bullying in the U.S. Workplace: Normative and Process-Oriented Ethical Approaches
}

\author{
Helen LaVan \\ Wm. Marty Martin
}

\begin{abstract}
Bullying is a serious problem in today's workplace, in that, a large percentage of employees have either been bullied or knows someone who has. There are a variety of ethical concerns dealing with bullying - that is, courses of action to manage the bullying contain serious ethical/legal concerns. The inadequacies of legal protections for bullying in the U.S. workplace also compound the approaches available to deal ethically with bullying. While Schumann (2001, Human Resource Management Review 11, 93-111) does not explicitly examine bullying, the five moral principles that he advocates can be applied to judge the ethics of bullying in the workplace. A possible limitation of this model is that, it is designed to be normative (judgmental), and while it does take into consideration the relationships among the victim, the perpetrator, the groups in the organization, and the organization itself in judging the ethics of bullying, it does not explicitly consider the process by which bullying might develop and persist. In order to gain a deeper understanding of the dynamics of this process, Nijhof and Rietdijk (1999, Journal of Business Ethics 20(1), 39-50)) suggest applying an A-B-C (antecedents, behaviors, and consequences) model to help understand the dynamics of bullying in the workplace. Formal propositions are offered to guide both academics and practitioners to an enriched understanding of the ethics of workplace bullying.
\end{abstract}

KEY WORDS: A-B-C-model, human resource management, legal, moral principles, workplace bullying

\section{Normative and Process-oriented Ethical Approaches}

To manage bullying in the U.S. workplace

While workplace bullying represents an ethical challenge from a number of perspectives, there does not seem to be conceptual models to facilitate the prevention and remediation of workplace bullying. Thus, the starting point for increasing ethical understanding is to formally offer the following propositions that can guide both academics and practitioners when addressing concerns in the workplace related to workplace bullying.

\section{Propositions}

1. The law offers an insufficient set of comprehensive remedies to prevent and remedy workplace bullying.

2. Workplace bullying is antithetical to Schumann's (2001) five moral principles of human resources management.

3. A more effective design of an ethical intervention to prevent and remedy workplace bullying is based upon an A-B-C analysis of workplace bullying as an ethical dilemma.

Consider an vast array of scenarios in organizational life regarding bullying:

- An employee is constantly criticized, ridiculed, and excluded from work related activities, but is fearful of reporting the bullying due to fear of retaliation. Individual.

- An employee is picked on for his/her manner of dress and unwillingness to go to lunch with coworkers. Individual.

- A manager views bullying as a legitimate managerial style, the most notorious of which is John Bolton, formerly Undersecretary of State of Arms of Control and Ambassador to the United Nations, whose bullying 
boss behaviors became part of his confirmation hearings and were featured in the media, including the Washington Post article entitled "Big Bad Boss Tales: Overbearing Management Styles Are All The Rage, Did We Say Rage?’' Individual.

- The desire of organizations to increase the diversity of its workforce directly results in bullying of the new entrants into the organization by individuals, who perceive their status is reduced as a result. Group.

- The union is in an untenable situation, when it has to represent both the victim and the bully in a grievance. Group.

- The organizational structure results in some groups being inferior to other groups, the latter of which take advantage of this. Organizational.

- A merger results in the employees of the company being acquired have an inferior status to the employees of the acquiring company. Organizational.

Bullying is commonplace (Namie and Namie, 2005; Quine, 1999; Zogby International, 2007), and relatively unregulated from a legal perspective. In addition, no ethical frameworks have been applied to assist in understanding the ethics of bullying. It is this absence in the ethical literature that this article hopes to address. This article is organized into the following sections: overall perspective on bullying, legal aspects of workplace bullying, examination of ethical models in the management of workplace bullying from both a normative ethical and processoriented ethical framework; and conclusion.

\section{Overview of Bullying}

\section{Definitions of workplace bullying}

There is no shortage of definitions of bullying and bullying in the workplace. Salin (2003) defines bullying as repeated and persistent negative acts toward one or more individual(s), which involve a perceived power imbalance and create a hostile work environment (Einarsen, 1996; Hoel and Cooper, 2000; Zapf et al., 1996). Bullying, is, thus a form of interpersonal aggression or hostile, anti-social behavior in the workplace. Salin states that several terms have been used to describe interpersonal aggression (see Keashly and Jagatic, 2003).

As for the term "bullying," it can be noted that it has been predominantly used by researchers in the U.K. and Ireland (Hoel et al., 1999; O’Moore et al., 1998; Rayner, 1997), Australia (McCarthy, 1996; Sheehan, 1996), and Northern Europe (Einarsen, 1996; Salin, 2001; Vartia, 1996), whereas German researchers (Zapf et al., 1996) have used the term "mobbing" for the same phenomenon. In North America, related and partly overlapping phenomena have been studied under a variety of different names: “employee abuse", (Keashly, 1998), "workplace aggression" (Neuman and Baron, 1998; O'LearyKelly et al., 1996), "victimization" (Aquino et al., 1999), “interpersonal deviance"(Bennett and Robinson, 2003), "social undermining" (Duffy et al., 2002) and "workplace incivility" (Andersson and Pearson, 1999; Cortina et al., 2001).

An equally wide variety of negative behaviors constitutes bullying: social isolation or silent treatment, rumors, attacking the victim's private life or attitudes, excessive criticism or monitoring of work, withholding information or depriving responsibility, and verbal aggression (Einarsen, 1996; Keashly, 1998; O'Moore et al., 1998; Zapf et al., 1996). Compared to forms of workplace violence, physical violence tends to be rather rare in bullying. However, bullying is interpersonal by nature, and is thus a narrower concept than anti-social or deviant workplace behavior, the latter of which may also involve acts directed toward the organization (Giacalone and Greenberg, 1997; Robinson and Bennett, 1995). Bullying typically takes place between members of the organization, in contrast to other forms of interpersonal violence and aggression, which may involve outsiders. Einarsen and Skogstad (1996) and Vartia (1996) stress that bullying is repeated, persistent and continuous behavior. Typically, single negative acts are not considered bullying. In contrast to much of the literature on workplace aggression (Neuman and Baron, 1998) and social undermining (Duffy et al., 2002), intent is typically not part of the definition, but instead the subjective perception of the victim is stressed (Hoel et al., 1999).

Bullying is typically targeted toward one or a few selected victims, rather than being a form of more generalized workplace incivility. Furthermore, bullying shows many similarities with sexual harassment 
in workplaces, even if the sexual element is missing. The concept of "hostile work environment" has been adopted from existing definitions of sexual harassment (Pryor and Fitzgerald, 2003), showing that both phenomena are different forms of workplace harassment, which have severe consequences for the well-being and job satisfaction of the target.

Bullying has also been conceived of, in the words of a popular website dealing with workplace issues "Workdoctor.com," as the "next and different harassment." It is thrice more prevalent than Illegal and discriminatory harassment (Namie and Namie, 2006). Civil rights claims require only that targets be a member of a "protected status group," but bullying ignores race, gender, age, and religion. Bullies are equal opportunity abusers.

Moreover, bullying has been seen as involving a power imbalance or a "victim-perpetrator" dimension, i.e., the target is subjected to negative behavior on such a scale that he or she feels inferiority in defending himself or herself in the actual situation (Einarsen and Skogstad, 1996; Keashly, 1998).

To date, there are equivocal findings regarding the necessity of power differences in situations involving workplace bullying. It has been suggested by some researchers that conflicts between parties of perceived equal strength are thus not considered bullying (Einarsen and Skogstad, 1996; Vartia, 1996). Others have asserted that formal power differences are a possible source of such an imbalance in power, but in contrast to, for example, "petty tyranny" (Ashforth, 1994), bullying is not limited to vertical aggression from supervisors toward subordinates. As power imbalances can also be the consequence of other individual, situational or societal characteristics (Cleveland and Kerst, 1993), the required power differences can also arise among peers. In some cases even subordinates, especially if acting in a group, may muster enough power to bully a supervisor. In addition, it should be noted that power imbalances may also evolve over time and that the bullying process itself may give rise to further increasing power imbalances.

The sources of power that exist for those that bully are broader than formal, legitimate power. One of the most widely cited typologies of power was developed by French and Raven (1959). This typology classifies power into these categories: reward power, coercive power, legitimate power, expert power, and referent power. Hodson et al. (2006) conceptualize power from a relational perspective that can account for power imbalances between superiors and subordinates and among peers.

Since there is no consensus regarding a definition of bullying and since victims of bullying might be reluctant to report, the authors are acknowledging that the prevalence rates may not be precise. Even given this definitional limitation, the empirical research on the prevalence of workplace bullying in Europe and the U.S. shows two phenomena. First, the research indicates that workplace bullying is not a marginal phenomenon. In the U.S., approximately 1 in $6(16.8 \%)$ workers are victims of workplace bullying (Namie and Namie, 2000). In Europe, the prevalence rate of workplace bullying is $11 \%$ (Paoli and Merllie, 2001). The second is that downward workplace bullying is the most prevalent. Downward bullying has been defined as "...the intentional and repeated inflictions of physical or psychological harm by superiors on subordinates within an organization" (Vandekerckhove and Commers, 2003, p. 41). According to a U.S. study (Namie, 2000), downward bullying makes up $81 \%$ of all workplace bullying cases. In Europe, although most research suggests it is slightly lower, the downward form is still the most prevalent: 57\% (Quine, 1999), 47\% (Kistner, 1997). A U.K. survey of members of a large public service union (Rayner, 1999; Unison, 1997) showed that in $63 \%$ of bullying cases, there is but one "bully" and in $83 \%$ of the cases the bully was a manager. "Survey of Employee Bullying," a study produced by the University of Manchester Institute of Science and Technology (UMIST, 2001) has demonstrated the prevalence of bullying in the U.K., with $50 \%$ of respondents reported to either having been bullied or to have witnessed such behavior, and $75 \%$ of reported cases perpetrated on employees by a more senior manager or employee. Research by the Manufacturing, Science and Finance Union in the U.K. showed a similar level of bullying (quoted in Rayner, 1999).

Bullying is rife across U.K. organizations (Anonymous, 2005), according to research published recently by the Chartered Management Institute. "Bullying at Work: The Experience of Managers," published in association with Unison and ACAS, the Advisory Conciliation and Arbitration Service, 
reveals that $39 \%$ of all managers have been bullied in the past three years. Middle managers are the most bullied among the U.K. management population, with half (49\%) having suffered from such treatment. The research also found that the most common forms of bullying are misuse of power or position $(70 \%)$, verbal insults (69\%), and undermining by overloading or criticism (68\%).

It is imperative to keep in mind that bullying is many different behaviors called by many different names. This fact can change the whole context, including the legal environment, the individual- and victim-related factors, the legitimacy of certain supervisory change management style or power structures, the union's duty for fair representation, the quest for diversity, and the consequences of being the victim of bullying.

In the previous section of this article, workplace bullying has been operationally defined, and has been described from a prevalence perspective. In this next section, the legal aspects of workplace bullying will be presented.

\section{Legal aspects of workplace bullying}

To date, in the United States, there is no single, specific statute that governs workplace bullying in particular (Mack, 2005). In spite of this gap in the law, there are nonetheless several legal theories which address workplace bullying. The major legal theories include Civil Rights, Retaliation, Occupational Safety \& Health, Whistleblowing, Workers' Compensation, Assault/Battery/Defamation, Intentional Infliction of Emotional Distress, Intentional Infliction of Business Relationship, and Constructive Discharge. See Appendix I.

\section{Civil Rights}

Title VII (Civil Rights Act of 1964) affords legal protection for those members of protected groups against harassment and discrimination because of their legally protected status. This distinction requires teasing out, whether the employee was the victim of workplace bullying due to their protectedclass status or some other factor. In contrast, generic workplace bullying laws would cover behaviors not covered by anti-discrimination and harassment laws because they do not implicate a protected-class status.

\section{Retaliation}

In Burlington Northern \& Santa Fe Railway Co. v. White, the United States Supreme Court held that employers are liable for retaliation for discrimination complaint filing. If a worker is a victim of workplace bullying subsequent to filing a discrimination complaint or charge, then the anti-retaliation provision affirmed by the United States Supreme Court in 2006 affords legal protection.

\section{Occupational safety \& health}

The Occupational Safety and Health Act of 1970 was established "to assure so far as possible every working man and woman in the nation safe and healthful working conditions and to preserve human resources" (29 U.S.C. Sec. 651(b)). Additionally, under the General Duty Clause, Section 5(a) (1) of OSHA, employers are mandated to provide employees with a place of employment that "is free from recognizable hazards that are causing or likely to cause serious harm to employees."

Workplace bullying is considered to be a type of workplace violence (ILO, 2000). As such, workplace violence is seen as an occupational hazard. An occupational hazard represents an exposure to an employee which in some way increases other employees' chances of being harmed in some fashion either psychologically and/or physiologically (Leymann and Gustafsson, 1996; Kivimaki et al., 2003; Hoel et al., 2004; Vartia, 2001).

\section{Whistleblowing}

Werhane et al. (2004) define whistleblowing as "the reporting of violations of law, harm to individuals, and infringements of basic human rights (p. 91)." There is no comprehensive law that covers whistle blowing. The Occupational Health and Safety Administration agency enforces the Whistleblower Protection Act of 1989 as it applies to whistleblowing in those cases involving occupational health and safety. Employees are protected from any form of retaliation for raising complaints concerning workplace safety and health, including the reports of workplace bullying. Sarbane Oxley, extended the Whistleblowers Protection Act to employees of public companies (Berkowitz, 2004). However, this 
has become somewhat circuitous, in that this protection extends both to individuals who are first bullied and then file a claim or who are bullied after filing an unrelated claim, such as employer misconduct.

Wrongful discharge has also been applied by the courts to whistleblowing cases, especially if the case involves violations of public policy by the employer. Palmateer v. International Harvester (85 Ill. 2d 124, 421 N.E. 2d 876, 1981) found that a whistleblowing employee was subjected to wrongful discharge after he reported coworkers were involved in criminal activity. Sheets v. Teddy's Frosted Foods (179 Conn. 471 A $2 d$ 386, 1980) found that a whistleblowing employee who insisted that the company comply with the Food, Drug, and Cosmetic Act had been wrongfully discharged.

\section{Workers' Compensation statutes}

It must be noted that this act defines workplace bullying relatively narrowly, that is, as a physical act rather than a psychological act.

\section{Assault/Battery}

Assault and battery fall under the umbrella of criminal law in contrast to civil law, which governs most of the cases of workplace bullying. However, a United States Department of Justice, Federal Bureau of Investigation (F.B.I.) report entitled "Workplace Violence: Issues in Response" (2004) identifies bullying as one type of workplace violence.

\section{Intentional infliction of emotional distress}

According to Mack (2005), intentional infliction of emotional distress is the primary legal theory in workplace bullying cases and falls under the general theory of torts.

\section{Intentional interference with a business relationship}

This legal theory is similar to constructive discharge. In Eserhut v. Heister (1988), the ruling of the Washington court was that the conduct of an employee's coworkers intentionally interfered with the plaintiff's contractual relationship with his employer, resulting in the plaintiff resigning from his employer. This might also be construed as constructive discharge had the employer tacitly allowed the bullying.

\section{Constructive discharge}

In Pennsylvania State Police v. Nancy Drew Suders in the U.S. Supreme Court on June 14, 2004, Justice Ruth Bader Ginsberg delivered the opinion and further defined what is required of the plaintiff to support a claim of constructive discharge. The plaintiff "...must show that the abusive working environment became so intolerable that her resignation qualified as a fitting response" (p. 1). This particular case was related to sexual harassment, but parallels have been drawn earlier in this article between sexual harassment and workplace bullying.

This definition focused upon "...(1) abusive conduct, (2) which causes the employee to resign, and (3) when, prior to resigning, the employee brings to the employer's attention the existence of the abusive conduct, and (4) the employer fails to take reasonable steps to eliminate the abusive conduct (p. 3)."

This discussion of the legal aspects of workplace bullying highlights several legal remedies that can be advanced to address workplace bullying. The law represents a minimum standard of ethical conduct. Yamada (2000a) views the development of employer policy as the best approach to affording protection.

\section{Ethical Concerns in the Management of Bullying}

Normative and process - oriented ethical approaches: going beyond the minimum

Ethical frameworks in the management of workplace bullying will be discussed from two separate, but related perspectives: a normative model and a process-oriented model. A normative model enables one to categorize and clarify the type of ethical violation, while a process-oriented model allows practitioners to design preventive and interactive approaches to workplace bullying.

\section{Normative model of managing workplace bullying}

The normative model of managing workplace bullying is drawn from the moral principles framework (Schumann, 2001). The moral principles framework consists of five complementary moral principles. 
These principles are: utilitarian, moral rights, distributive justice, care ethics, and virtue ethics (Schumann, 2001). Detailed descriptions of these moral principles, which are not mutually exclusive, are well developed in the ethics literature and beyond the scope of this article.

This framework has been applied to a variety of human resources management issues, ranging from employment discrimination to sexual harassment. Schumann (2001) calls for future researchers to apply the moral principles framework to other areas within human resources management. The authors of this article suggest that this framework can be applied to make ethical decisions about workplace bullying.

\section{Utilitarian moral principle}

Utilitarianists are consequentialists. At the heart of any utilitarian theory is a concern for consequences. Schumann (2001) comments that an "action must do the most good and the least harm to be considered ethical." (p. 97). Tracy et al. (2006) describe the direct costs, such as workers' compensation claims, and the indirect costs, such as high staff turnover, of workplace bullying. It can be argued that these costs represent harm to the organization and the individual. One such consequence that has an impact on both the organization and the individual is declining job performance resulting from workplace bullying. Targets of workplace bullying "liken themselves to vulnerable children, slaves, prisoners, animals, and heartbroken lovers." (Tracy et al., 2006, p. 148) Based upon Schumann's (2001) moral principles framework, workplace bullying is an action that results in more harm than good. As such, workplace bullying is not ethical.

\section{Moral rights principle}

According to Crane and Matten (2004), rights are "certain basic, important, inalienable entitlements that should be respected and protected in every single action." (p. 173). Kant (1981) asserts that is it wrong to treat another person only as a means. A key question is whether moral rights extend to employees. Werhane et al. (2004) argue that moral rights do extend to all employees and that these employees "are entitled to certain rights - moral rights - regardless of the particulars of the working conditions, economic exigencies, cultural biases, religious prohibitions, and so on." (p. 29). The rights of workers and the duties of employers are intrinsically intertwined (Maitland, 1989). One such right is a right to well-being in general and a right to safety in the workplace (Ariss, 2003).

Another key question is whether workplace bullying poses a threat to the right to worker well-being and safety. The International Labour Organization classified bullying as a type of workplace violence (2000). Workplace bullying is empirically associated with various psychological and physical symptoms (Hoel et al., 2004; Kivimaki et al., 2003; Leymann and Gustafsson, 1996; Vartia, 2001). The right to worker well-being and safety is compromised by workplace bullying, and such behavior is unethical. Schumann's (2001) three-pronged test to determine the moral rights of others would yield the same conclusion about the ethics of workplace bullying from a moral rights perspective.

\section{Distributive justice}

Distributive justice refers to what actions produce a fair distribution of benefits and costs for all stakeholders. Based upon the work of John Rawls, Freeman (1994) asserts that organizations ought to be managed and governed in the interest of all stakeholders, including employees. Distributive justice is based upon an economic view in which production is dependent upon cooperative activity (Zucker, 2000).

If assessed using the principles of distributive justice, workplace bullying is unethical because it diminishes the potential productivity for stakeholders, that is, employees. This represents interference with the work of targets of bullying, thereby constraining the potential for cooperative activity.

\section{Care ethics}

Care ethics assume that humans live and work in relationships with "actual flesh-and-blood other human beings for whom we have actual feelings and with whom we have real ties." (Held, 1993, p. 58). According to Herr (2003), "morality is instrumental to forming and maintaining caring relationships." (p. 474). These feelings of care create rights and responsibilities (Werhane et al., 2004). As such, caring is not exhibited in any incident of workplace bullying. This lack of caring in these bullying incidents does not result in forming and maintaining caring relationships, and are thus unethical. 
Virtue ethics

Virtue ethics focus on what makes a good person, rather than what makes a good action. The ethical claims upon a virtuous agent must meet three conditions: to distinguish between good and bad and right and wrong actions; to act because the action is good and/or right; and to act with consistency, or to be reliable and dependable (Halwani, 2003). It is assumed that workers at all levels in corporations are agents, but one may ask are they making decisions and behaving as virtuous agents? Clearly, the act of workplace bullying performed by an agent of the workplace dilutes one or all of the ethical claims upon a virtuous agent. In short, workplace bullying is unethical using a virtuous agent analysis.

\section{Process-oriented model of workplace bullying}

However more is required than an after-the-fact taxonomy of behaviors. The ability to neatly categorize a type of ethical violation is useful but limited in that it does nothing to ameliorate, much less eliminate, bullying from the workplace. More is required. Thus we turn to a more process-oriented model.

The proposed process-oriented model of workplace bullying seeks to identify the specific loci of the ethical concerns of managing workplace bullying by analyzing the antecedents, behaviors, and consequences of workplace bullying at three levels of analysis: organizational, group, and individual. These loci of concern will be described in detail later in this article after addressing this process-oriented model of workplace bullying.

The process-oriented model of workplace bullying draws upon the work of others in the area of organizational behavior management in general (Bucklin et al., 2000), and the three-term contingency or A-B-C model of behavior in particular (Boyce and Geller, 2001). The A-B-C model of behavior has been applied to ethical issues in business settings (Nijhof and Rietdijk, 1999) as well as issues related to occupational safety and health (Boyce and Geller 2001; Geller, 1996).

In this model, an antecedent (A) is a stimulus which precedes a behavior (B). In short, antecedents trigger behavior. A consequence $(\mathrm{C})$ is an event that follows a given behavior, resulting in strengthening, maintaining, and/or extinguishing the given behavior. In short, consequences motivate behavior (Geller, 1996). For example, in the cases and scenarios to follow, it is apparent that the behavior in question is workplace bullying, realizing that there are different types of workplace bullying depending upon the context of the specific situation. Illustrative situations will be presented to more fully describe the qualitative and contextual nature of workplace bullying.

This process-oriented model of workplace bullying is applicable, not only in understanding the ethical aspects of workplace bullying, but also in designing interventions to decrease the prevalence of workplace bullying and to respond to incidents of workplace bullying in a more ethically robust manner.

In the A-B-C process-oriented approach to workplace bullying, the role of managers is essential from two perspectives. First, the manager assumes the role of a diagnostician. Second, the manager assumes the role of an interventionist. When the manager is acting as a diagnostician, the manager is identifying antecedents (A), triggers, or causes behavior associated with workplace bullying. After the manager has targeted the precise antecedents (A), then the manager describes the behaviors (B) associated with workplace bullying in terms of its frequency, duration, intensity, and appropriateness, in order to formulate an intervention plan. In most instances, the manager assuming the role of the interventionist has to consider what consequences (C) or responses will be imposed upon the workplace behavior (B) being attentive to concepts like positive reinforcement, negative reinforcement and even punishment, although ill-advised. Moreover, the manager must be certain about the timing of this managerial approach to workplace bullying. Any intervention should occur as close as possible in time with the demonstrated behavior. When managers are designing assessment techniques to identify the antecedents (A) and the consequences (C) or response to the behavior (B), they must realize that interventions will fall into two categories: formal and informal and at three levels: individual, group, and the organization. As such, any managers will be operating from a $2 \times 3$ intervention matrix as illustrated in Table I. 


\section{TABLE I}

Managerial intervention matrix

\begin{tabular}{|c|c|c|}
\hline A-B-C Model & Formal & Informal \\
\hline Antecedent & $\begin{array}{l}\text { Investigation processes aimed at identifying } \\
\text { triggers. } \\
\text { Quality management processes aimed at } \\
\text { identifying causes. } \\
\text { EAP processes aimed at identifying vulnerability } \\
\text { to bullying and at risk behaviors among } \\
\text { employees who have bullied in the past. } \\
\text { Employee selection processes aimed at identifying } \\
\text { candidates who are more likely to be bullied } \\
\text { at work. }\end{array}$ & $\begin{array}{l}\text { Unconscious signals sent by management that } \\
\text { bullying will or will not be tolerated. } \\
\text { Bypassing and/or working around formal } \\
\text { investigation, quality management, EAP, and } \\
\text { employee selection processes aimed at } \\
\text { identifying individuals likely to be victims } \\
\text { of bullying at work. }\end{array}$ \\
\hline Behavior & $\begin{array}{l}\text { Incident report forms and tools that enable the } \\
\text { individual completing the form to describe the } \\
\text { behavior by level of the organization (e.g., } \\
\text { individual, dyad, group, organizational) and to } \\
\text { describe the behavior by specific characteristics } \\
\text { (e.g., frequency, intensity, duration, appropriateness). }\end{array}$ & $\begin{array}{l}\text { Modeling of behaviors associated with } \\
\text { bullying or not associated with bullying. }\end{array}$ \\
\hline Consequence & $\begin{array}{l}\text { Disciplinary policies, procedures, and processes. } \\
\text { Ethical and codes of conduct policies, procedures } \\
\text { and processes. } \\
\text { Mediation policies, procedures, and processes. } \\
\text { EAP policies, procedures, and processes. } \\
\text { Workplace violence policies, procedures, and } \\
\text { processes. } \\
\text { Grievance policies, procedures, and processes. }\end{array}$ & $\begin{array}{l}\text { Conscious or unconscious reinforcement } \\
\text { of behaviors aligned with workplace bullying } \\
\text { or behaviors not aligned with workplace } \\
\text { bullying. } \\
\text { Patterns of denial in which complaints, } \\
\text { observations, and/or " tell- tale " signs. }\end{array}$ \\
\hline
\end{tabular}

The institutionalization of interventions aimed at preventing and addressing workplace bullying must include a multi-component package that addresses the antecedents, the behavior, and the consequences. As such, a more robust institutional intervention will include the following components: (a) elucidation of behavioral norms aligned with artifacts of organizational culture and perhaps included in codes of conduct; (b) education, training, development and modeling by supervisors and all other employees; (c) design of organizational structures, policies, processes, and practices to monitor and continuously improve all interventions; (d) development of organizational, managerial, and team consequences for not engaging in workplace bullying as well as consequences for engaging in behaviors associated with organizational citizenship and even peace; and (e) enabling individuals to tap into their own emotional intelligence and act in ways that are antithetical to workplace bullying (Boyce and Geller, 2001;
McSween and Mattews, 2001). What follows is an application of the A-B-C ethical model (Nijhof and Rietdijk, 1999) to workplace bullying as a way to describe or identify the loci of the concern, followed by illustrative scenarios of workplace bullying organized by the loci of concern: individual level of analysis, group level of analysis, and organizational level of analysis (as shown in Appendix II).

\section{Antecedents of workplace bullying}

The antecedents of workplace bullying exist at the organizational, group and individual levels. The antecedents of workplace bullying at the organizational level include, but are not limited to, the culture of the organization, the current challenges to the organization, and the existence of consistently enforced policies and procedures. Group level antecedents include the climate of the particular team and the influence of peers. Also included are the individual level antecedents, which include two 
primary drivers: (1) perpetrator factors and (2) victim factors. This conceptualization builds upon the work of Salin (2003), who described the antecedents of workplace bullying at the individual level (e.g., dissatisfaction and frustration), at the group level (e.g., internal competition, changes in work group composition), and at the organizational level (e.g., downsizing and restructuring).

\section{Behaviors of workplace bullying}

Workplace bullying is an action performed by one individual against another individual. As previously noted, workplace bullying is an interpersonal behavior. A behavioral analysis perspective offers a more refined analysis by describing behavior along several dimensions including intensity, frequency, magnitude, duration, and appropriateness with regard to age, setting, circumstance, and role. Hence, behaviors can differ both qualitatively and quantitatively.

\section{Consequences of workplace bullying}

The consequences of workplace bullying involve all three levels of analysis. At the organizational level, the response to workplace bullying typically involves the human resources department, which may act alone or in collaboration with internal partners (e.g., general counsel, union steward, and the Employee Assistance Plan [EAP]) and/or external parties (e.g., EEOC). At the group level, the human resources department and the immediate manager and in some cases members of the work group may act formally or informally, as evidenced by efforts at team development and mediating between two or more parties. At the individual consequences level, human resources, the immediate manager, the perpetrator and the victim might all be involved in different ways with internal resources (e.g., EAP, union steward, interpersonal skills course, and assertiveness course) and external resources (e.g., private therapist). Another possible consequence of bullying at the individual, group, and organizational level is reduced job performance for the victim. This consequence can affect future behaviors.

Another aspect of the consequences of workplace bullying is to what degree the organization provides formal consequences to prevent and remedy instances of workplace bullying as built into the organizational infrastructure including policies, procedures, practices, processes, and resources. A related aspect is the manner in which agents of the organization, including human resources, and the managers involved in any single instance of workplace bullying, consistently enforce the existing policies and practices and follow the promulgated procedures and processes.

It must be noted that there are instances of workplace bullying in which external agencies and parties become involved and these situations typically involve the legal system. Hence, the violation of law is yet another, and formal, consequence. Also, the law may serve as an antecedent to workplace bullying by preventing the manifestation of such behavior out of fear of legal consequences of engaging in such behavior.

The law, both statute and case law, often serves as a formal consequence, sanctioned by society to respond to behavior which is deemed a threat to civil society, democratic society, and the general safety, health, and well-being of the public.

\section{Manifestations of workplace bullying}

Appendix II illustrates both the normative model of workplace bullying based upon the work of Schumann (2001) and the process-oriented model or A-B-C model based upon the work of Nijhof and Rietdijk (1999). In addition to these models, Appendix II also specifies the loci of concern of workplace bullying and the manifestations organized by the individual, group and organizational levels of analysis. The following scenarios illustrate the dynamic interplay of organizational factors, situations, and the manifestations of workplace bullying along with an application of the A-B-C model. The cases presented will provide a deeper and broader understanding of the triggers and possible set of intended and unintended consequences following the manifestation of workplace bullying.

\section{Individual Level}

Consider the following individual level bullying scenarios:

- An employee is constantly criticized, ridiculed, and excluded from work related activities, but is fearful of reporting the bullying due to fear of retaliation. 
- An employee is picked on for his/her manner of dress and unwillingness to go to lunch with coworkers.

- A manager views bullying as a legitimate managerial style, the most notorious of which is John Bolton, formerly Undersecretary of State of Arms of Control and ambassador to the United Nations, whose bullying boss behaviors became part of his confirmation hearings and were featured in the media, including the Washington Post article entitled "Big Bad Boss Tales: Overbearing Management Styles Are All The Rage, Did We Say Rage?”

At the individual level of analysis, two central organizational victims in workplace bullying will be highlighted as well as the manifestations of workplace bullying relative to these organizational perpetrators. The applicable moral principles at the individual level using Schumann's framework of ethical issues within human resources management are care ethics, distributive justice, and moral rights.

\section{Individual level: victimization issues}

(Consequences + Antecedents)

There are individual factors relating to the ethical concerns in bullying. Bullying is underreported, but encouraging reporting by the victim may lead to retaliation by the bully. There are ethical issues surrounding the victim, including the tendency to blame the victim or the tendency for the victim to either have certain personality characteristics or engage in certain "baiting behaviors" that precipitate the victimization. "Baiting behaviors" represent antecedents, and victimization is a type of consequential experience. Other issues related to the victim include underreporting, retaliation, confidentiality, blame the victim, innocent victim, fleeing or withdrawing response, and the elaboration of victim factors.

\section{Underreporting (Consequence + Antecedent)}

Victims may not see themselves as bullied, but instead feel to blame for provoking antagonism. Evidence is also a problem. Victims are likely to keep silent through fear or shame, there will probably be no witnesses, and the aggressor may well be in a position of authority (Bernardi, 2001; LePoidevin, 1996). A further survey by the U.K. public sector union Unison found, in addition, that $95 \%$ of workers were too scared to report bullying, and a roughly equal number felt that the perpetrator would rarely be sanctioned, understandable perhaps given that $73 \%$ of respondents revealed that they felt management were fully aware but inactive in cases of bullying (UNISON, 1997).

Underreporting becomes an ethical concern, if a system is set up to facilitate reporting and no or insufficient actions are taken. Without repercussions, the bullying may get worse and the victim may feel of the increased hopelessness. Underreporting represents both an antecedent and a consequence.

\section{Retaliation response (Consequence)}

In a large study of union members in the U.K. conducted by Unison, patterns of consistency were found between targets and non-targets in attitude questions regarding the causes of bullying. However, the effectiveness of actions taken by targets of bullying showed that bullying rarely stopped as a result of action by targets. Advising targets to discuss the situation with the bully without professional support is probably misguided, as retaliation was likely (Rayner, 1999). Retaliation represents a consequence.

\section{Confidentiality (Consequence)}

Issues of confidentiality arise when the victim seeks out a manager in confidence, and the manager thus has a concern about whether to disclose the bullying to the proper channels in the organization for resolution. Additionally, there may be legal protections for confidentiality if the victim (or bully) seeks help from the resources in an Employee Assistance Plan. There may be legal requirements not to disclose under the confidentiality provisions of HIPPA. Hence, how can the organization effectively manage what it does not know-often does not have a legal right to know what is taking place? Confidentiality represents a consequence.

Blame the victim (Antecedent + Consequence)

Statistics show that frequently there is a tendency to blame the victim (Bernardi, 2001). Bullying has historically gone unchecked and has been dismissed as a personality conflict, an employee attitude or a 
strong management style. At other times the bully simply alleges that the victim is incompetent or insubordinate and senior management accepts this characterization without question. This represents both an antecedent and a consequence.

\section{Innocent victim? (Antecedent)}

On the other hand, some victims may have engaged in perceptions or behaviors that precipitated the bullying. Aquino et al. (1999) investigated the conditions under which employees are more or less likely to become targets of coworkers' aggressive actions. Results from a field survey showed people high in negative affectivity more often perceived themselves as victims, as did people who were low in the selfdetermination component of empowerment. In addition, hierarchical status appeared to buffer the influence of negative affectivity: Negative affectivity was not related to indirect victimization for higherstatus people but was positively related to indirect victimization for lower-status people. This represents an antecedent, perhaps a non-obtrusive one. The ethical challenge becomes how management fosters a climate in which victim blaming is not permitted at the same time that victim baiting is also not permitted?

\section{Fleeing or withdrawing as a response (Consequence)} Wormald (2005) and Ayoko et al. (2003) caution about turnover and absenteeism, and the costs of recruitment and training. On one hand, there is lost productivity because of the bullying, but on the another hand, it becomes easier if the victim leaves. However, it is not managerially easier if the victim stays, but is absent or has lower productivity. This represents a consequence.

\section{Elaboration of victimization actors}

Individual factors include such issues as underreporting, retaliation, and confidentiality. Victim factors include blaming the victim, baiting the victim, and physical and psychological harm. Victim factors are closely related to individual factors except that the individual factors are more interactional and victim factors more personal.

\section{Cases}

A bookkeeper was constantly bullied by her coworkers. They constantly criticized, ridiculed, and excluded her from work related activities. She was reluctant to report this to her supervisor due to fear of retaliation.

\section{Individual level: perpetrator issues}

\section{Antecedents}

There can be no target or victim of workplace bullying without another organizational actor, including the perpetrator whose attitudes, style and behavior often serve as an antecedent to the behavior itself. As such, managerial style and structure, legitimate managerial style, and managerial style factors will be discussed below.

\section{Managerial style and structure (Antecedent)}

It may be that the nature of organizational life, including managerial processes and power structure in organizations, fosters bullying. This represents an antecedent.

\section{Legitimate managerial style (Antecedent)}

Sometimes bullying can be a legitimate managerial style. John Bolton's nomination as U.N. ambassador put the word "bully" on the front page when a colleague described Bolton as the "quintessential kiss-up, kick-down sort of guy." (Wormald, 2005). Hutchinson et al. (2005) and her colleagues have a similar viewpoint, when they point out that often organizational change can be a vehicle for legitimizing bullying.

\section{Elaboration of perpetrator factors}

As it relates to managerial style factors, this type of bullying relates to how managers purposely treat employees. Occasionally, the manager is unaware that the managerial style is thought of by subordinates as bullying, but most often the manager does not care. He or she takes the perspective that "do it my way or else" is the proper style. This represents an antecedent.

\section{Group Level}

Consider the following group level bullying scenarios:

- The desire of organizations to increase the diversity of its workforce directly results in 
bullying of the new entrants into the organization by individuals who perceive their status is reduced as a result.

- The union is in an untenable situation when it has to represent both the victim and the bully in a grievance.

At the group level of analysis, there are two manifestations worth describing, that is, the group cohesiveness types of bullying and the power-based types of bullying. The applicable moral principles at the group level using Schumann's framework of ethical issues within human resource management are utilitarian ethics, moral rights, and distributive justice.

\section{Group cohesiveness types of bullying (Antecedent)}

The main difference between power-based bullying and cohesiveness bullying is that in the powerbased bullying, the formal structure precipitates the bullying. In the group cohesiveness type, it is the informal group which precipitates it. As an illustrative example, group cohesiveness bullying is created by a situation in which there is high degree of cohesiveness, but some group members are not a part of the "in-group". These outsiders can become the victims of the bullying. Another illustration of this type of bullying involves managerial style, as again exemplified by former Ambassador Bolton. This would also include such factors as public criticisms and humiliating the employee in front of coworkers. This represents an antecedent.

\section{Power-based bullying (Antecedent)}

This type of bullying is the result of enabling structures within the organization. It comes about because of issues of members' status, group status, and its equal impact on individuals and coworkers. Utilitarian, moral rights and distributive justice are the principles of Schumann's framework that would be most applicable. An illustrative example of power-based bullying is a situation in which departments have unequal status. When they have to collaborate on a project, the group with the greater status bullies the group with the lesser status. This represents an antecedent.

\section{Organizational Level}

Consider the following organizational level bullying scenarios:

- The organizational structure results in some groups being inferior to other groups, the latter of which take advantage of this.

- A merger results in the employees of the company being acquired have an inferior status to the employees of the acquiring company.

At the organizational level of analysis, there are three loci of concern that will be explored: power structure, union, and the existence of diversity. The applicable moral principles at the organizational level using Schumann's framework of ethical issues within human resources management are utilitarian ethics, moral rights, distributive justice, virtue ethics, and care ethics.

Inherent in the power structure of formal organizations (Antecedent + Consequence)

It may be that the potential for bullying is inherent in the power structure of the formal organization. Salin (2003) has noted that in organizations there are enabling structures or necessary antecedents (e.g., perceived power imbalances, low perceived costs, and dissatisfaction and frustration), motivating structures or incentives (e.g., internal competition, reward systems and expected benefits), and precipitating processes or triggering circumstances (e.g., downsizing and restructuring, organizational changes, changes in the composition of the work group). Salin's (2003) conceptualization of workplace bullying is similar to the process-oriented model of workplace bullying proposed in this article as evidence by the similar concept of antecedents and enabling structures/necessary antecedents. This also represents a consequence.

The perspective of Heames et al. (2006) is similar. They found that group composite factors impact on co-worker job satisfaction (individual member status rankings, status inhibitors, individual's feeling of group satisfaction, and individual member behavior reaction).

Or it could be that as organizations change, a new power/knowledge bond sets forth new rules of 
rights. Then downward workplace mobbing (bullying) could be seen as manifestation of power outside of the delineations drawn by these new rules of right. In other words, downward workplace mobbing has been described as pathological because the current organizational climate does not embrace the full ethical potential of excellence, adventure, creativity, and responsibility (Vandekerckhove and Commers, 2003).

Unions and the duty to fairly represent (Consequence) The concern facing unions in this context is somewhat unique, and it certainly is not new. One aspect of this is the need to balance scarce resources in the union representation process. Also, the union must balance the rights of individuals against those of the group. Moreover, the duty to protect the rights of individuals may, in some instances, include those whom the union dislikes, such as minorities, women, or particularly obnoxious co-workers. This is not unlike the obligation imposed on management to treat union workers fairly even when management harbors negative feelings toward such workers. Upto the extent that unions do a good job in fair representation situations, they may gain greater understanding of the pressure and problems that face management (Adler and Bigoness, 1992).

The role of the union is to represent union members in work environment grievances. If bullying results in a grievance or an unfair labor practice charge, the union has the duty to represent both the bully and the victim. While not unlike the role of the union in sexual harassment contexts, the union is in the middle. However, sexual harassment is illegal, whereas bullying is not necessarily so. Schumann's principles that would be applicable would be rights, utilitarian, justice and virtue. As an illustrative example of the duty of fair representation, it is not inconceivable that if the victim grieves the bullying, and the union represents him or her, the bully can sue the union for failure in its duty to fairly represent. This represents a consequence.

Diversity increases potential for bullying (Antecedent + Consequence + Behavior)

There is the perspective that the goal of increasing diversity within formal organizations might add to conflict and bullying. Many researchers have pointed this out, including Bagshaw (2004), Heames et al. (2006), Jehn et al. (1999), Pelled (1996) and Ayoko et al. (2003). Thus, it appears that in the striving for diversity, generally considered to be a highly desirable equal opportunity strategy, the potential for bullying is increased. This represents both an antecedent and consequence.

\section{Diversity bullying (Antecedent)}

In the striving for diversity in the workplace, the likelihood of bullying probably increases. Of all types of bullying, this type has the potential for being the most legally protected, especially under Title VII protections. Schumann's moral principles would include rights, justice and caring for racially, sexually and national origin diversity. An illustrative example of diversity and bullying are those situations in which bullying based on ethnic/national origin is subtle and not always immediately identifiable. For example, there are rivalries among different ethnic Hispanics. The legal status of Hispanics from Puerto Rico is sometimes contrasted with the illegal status of Mexican and Central American Hispanics. Conflicts based on ethnic diversity in other countries, such as Middle Eastern nations, Greece and Turkey, and Ireland may manifest themselves in U.S. workplace in the form of bullying.

\section{Conclusion}

Workplace bullying is a complex organizational phenomenon with ethical implications both within and outside any given organization in which workplace bullying occurs. Referring back to the three propositions highlighted at the beginning of this article, it seems evident that the law is necessary but insufficient in both understanding and formulating a comprehensive remedy in the prevention and resolution of workplace bullying. It is also evident that Schumann's five moral principles within his ethical framework of human resources management can be directly applied to categorize the type of ethical violation in those situations in which workplace bullying occurs. This application of Schumann's ethical framework was referred to as the normative model. The final proposition, that is, the application of the A-B-C model of Nijhof and 
Rietdjik and presented in this article as the processoriented model, was described as a methodology to design a preventive or restorative ethical intervention related to workplace bullying. Each of these provided some understanding, from a moral, legal, or behavioral system. Each by itself did not provide sufficient understanding.

While no specific legal bases applied to remedying workplace bullying in the U.S., laws, torts, and company policy do shape the regulation of bullying. The legal bases can be thought of as the antecedents of bullying behavior. However, legal bases in themselves are insufficient from an ethical understanding.

Schumann's five moral principles did apply to the analysis of bullying but with varying degrees of efficacy. These principles included utilitarian, rights, distributive, caring, and virtue principles. The varying levels at which bullying occurs, specifically the individual (victim or perpetrator), group, and organizational levels, complicate how the analysis is done.

The more process-oriented A-B-C model, which takes a more systematic perspective, allows for identifying antecedents, behaviors, and consequences of bullying. Managers can apply the A-B-C model by first organizing any data obtained from a complaint, incident report, investigation or observation by classifying the data in three categories: antecedents or triggers; the actual behavior or bullying; and the consequences or response at the individual, group, and organizational levels. After carrying out this analysis, then managers can formulate a managerial intervention aimed at eliminating or decreasing the frequency, magnitude, and duration of bullying behavior. Possible managerial recommendations include, but are not limited to the following: impose formal and informal consequences immediately after gathering data; reinforce the culturally appropriate, behavioral expectations; and consistently enforce any existing disciplinary policy or procedure being attentive to not being accused of being an "abusive supervisor." However, using this model by itself does not create an understanding of the ethical, moral frameworks provided by Schumann.

If one is a practitioner looking for ethical guidance about bullying, it will be necessary to examine legal bases, moral principles, and the antecedents and consequences of bullying behavior. If one is attempting to extend the body of knowledge on ethics as it relates to bullying, it will be necessary to collect case data and other empirical information to further advance knowledge about how bullying behavior transpires in the workplace - its moral frameworks, legal bases, and antecedents and consequences.

Practitioners can utilize both the normative model and the process-oriented model to analyze the situational issues related to workplace bullying as a way of designing and delivering preventive and restorative ethical interventions. Academics can conduct research to further elucidate the theoretical aspects of these two models and to determine the most efficacious aspects of them by formulating hypotheses, testing hypotheses, and interpreting the findings from any qualitative or quantitative investigations aimed at furthering our understanding of workplace bullying as an ethical issues (Table II).

TABLE II

Overview of applicability of Schumann's ethical principles to bullying

Bullying violates the ethical principle of utilitarianism in that bullying results in negative organizational consequences.

Bullying violates the ethical principles of moral rights, in that the rights of the victim and perhaps of the organization are in conflict.

Bullying violates the ethical principles of distributive justice in that neither the victim nor the organization receives just rewards for efforts.

Bullying violates the ethical principle of care in that not only is it difficult, if not impossible, for the individuals involved caring for each other, but other employees may have feelings of empathy or antagonisms toward the victim and bully respectively.

Bullying violates the ethical principle of virtue in that the bully is acting in a manner that is not virtuous, in that he or she is not distinguishing between good and evil, and is not acting with consistency and is not being reliable and dependable. 


\section{Acknowledgments}

The support of the Wicklander Fellow in Business Ethics is gratefully acknowledged.

\section{Appendix I}

\section{U.S. Laws Relating to Bullying (Summarized from Yamada, 2000a, $b$ and additional sources)}

Emotional distress claims

Some bullied employees have pursued personal injury lawsuits for intentional infliction of emotional distress (IIED) as a possible avenue of legal relief (Yamada, 2000a, b). The most successful types of workplace-related IIED claims are those grounded in allegations of severe status-based harassment or discrimination, or in allegations of retaliation for engaging in reporting or whistleblowing. Targets of "garden variety" workplace bullying, however, often have neither common law nor statutory avenues of relief. Courts have generally concluded that the activity was not sufficiently outrageous or extreme.

\section{Intentional interference with the contractual relationship}

Another possible cause of action is intentional interference with the contractual relationship. This type of action has occasionally occurred, when employees sued a supervisor for bullying and the courts have concluded that the bullying was unrelated to the company's corporate interests. Other torts claims could include assault, battery, and/or false imprisonment.

\section{Workers' Compensation}

Workers' compensation is a potential source of relief when workplace bullying has caused an employee to suffer partial or full incapacity. While it may be possible to bring a workers' compensation claim for intentional infliction of emotional distress, the state jurisdictions are split regarding the viability of doing so. Often, it is not possible to single out the bullying employee.

Discriminatory harassment-hostile environment and Americans with Disabilities Act

Harassment that is grounded in a target's protected class membership and might be actionable under both federal and state discrimination statutes. In particular, hostile work environment theory offers some potential relief to employees who are subjected to severe bullying at work on the basis of protected class membership. (Schultz, 2003).

This type of finding, however, is unusual, as for the most part bullying behaviors have not been grounds for relief in status-based harassment claims. In order to illustrate, Professor Vicki Schultz noted in her analysis of the evolution of sexual harassment law that many courts refuse to consider any harassing conduct that is not sexually explicit.

\section{Retaliation and whistleblowing}

The Whistleblower Protection Acts, of which there are both Federal and state versions, were originally enacted to protect employees from retaliation for disclosing employer illegality, such as investigation by a regulatory agency (Berkowitz, 2004; Gardner, 1999). Some state statutes protect public sector employees, but some have statutes which protect both public and private sector employees (BennettAlexander and Hartman, 2007).

Retaliation for rebuffing sexual advances, complaining of discrimination, participating in union organizing activities, or engaging in some type of whistleblowing behavior is a common motivation behind workplace bullying. If retaliation results in discharge, there may be legal coverage by the antiretaliation provisions of the respective legislation. Also, the public policy exception to the employment at will doctrine may apply. What this means is that although it is legal to fire an employee at will, if the discharge was based on behavior that is contrary to public policy, then the employer may not be able to terminate.

\section{Occupational safety and health laws}

Potentially the Occupational Safety and Health Act (OSHA) and its state counterparts could provide greater legal protections against bullying, especially now that workplace safety agencies are paying more attention to occupational stress. Furthermore, the OSHA can be used as the rationale for developing effective human resources programs to safeguard employees from bullying.

Unions and labor law

For the most part, organized labor has yet to recognize fully the problem of workplace bullying, 
although a small number of union activists and officers have been raising the issue. Recommended actions that unions can take include bargaining for contract provisions that protect members against abusive supervision; seeking protection under the concerted activity protections of the National Labor Relations Act, and having shop stewards can serve a valuable mediating role in bullying situations, including those between union members.
Employer policies

Although employer sexual harassment policies have become an employment relations standard, workplace bullying policies is a rarity. However, a small number of employers, including IBM, the Oregon Department of Environmental Quality, and the Massachusetts Institute of Technology, proscribe general harassment and bullying behaviors in their employee policies and include them in their internal complaint procedures.

\section{Appendix II}

Comparing Schumann and the ABC framework in analyzing ethical underpinning of bullying

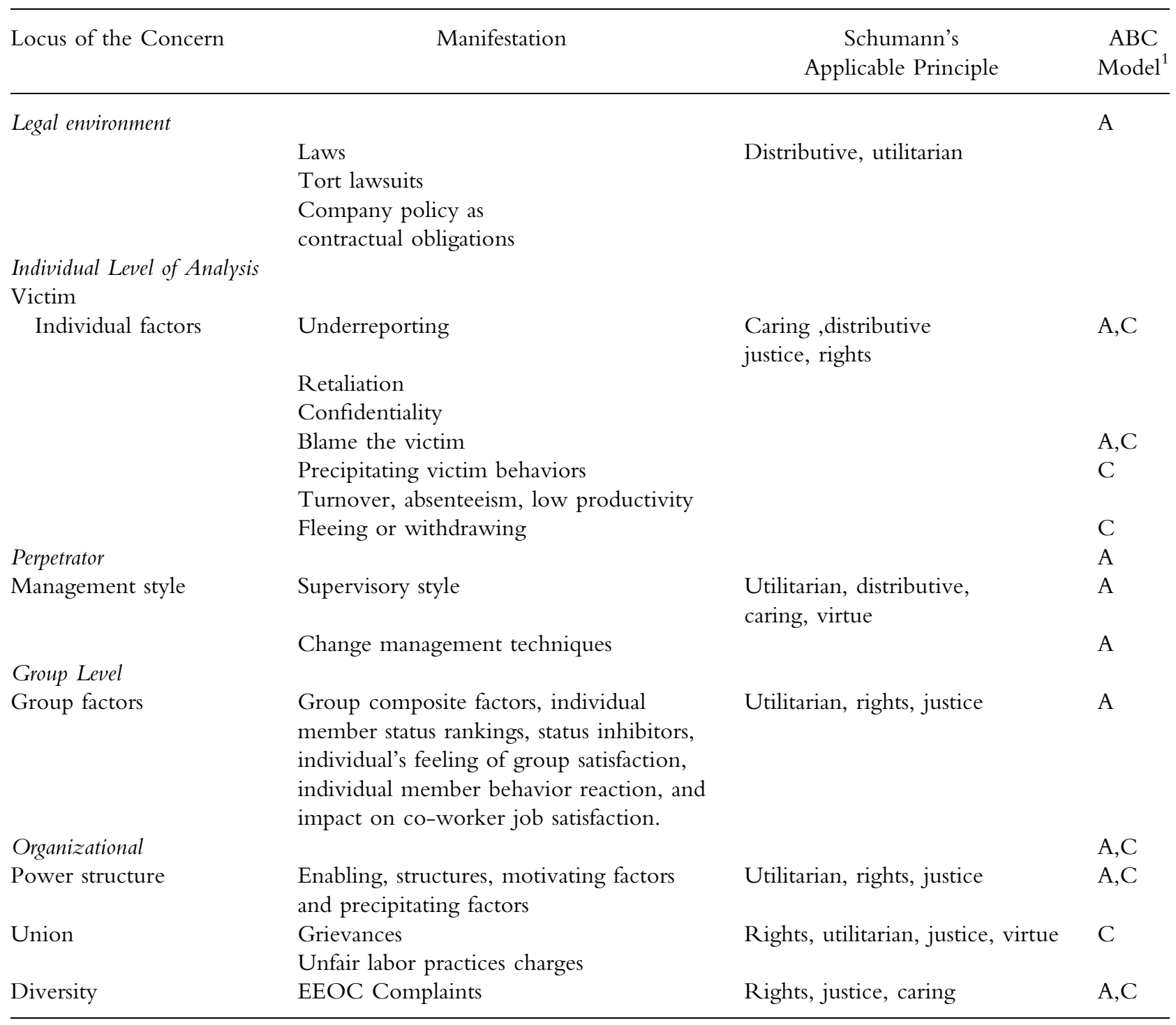




\section{Note}

1 The reader should be cognizant of the fact that the " $\mathrm{B}$ " components of the ABC model are listed in the manifestation column.

\section{References}

Adler, R. S. and W. J. Bigoness: 1992, 'Contemporary Ethical Issues in Labor-Management Relations', Journal of Business Ethics 11(5-6), 351-360.

Andersson, L. and C. M. Pearson: 1999, 'Tit for Tat? The Spiraling Effect of Incivility in the Workplace', Academy of Management Review 24(23), 452-471.

Anonymous: 2005, 'Bullying Amongst Managers Rockets as Organizations Fail to Take Action', Management Services 49(4), 12-13.

Aquino, K., S. L. Grover, M. Bradfield and D. G. Allen: 1999, 'The Effects of Negative Affectivity, Hierarchical Status, and Self-Determination on Workplace Victimization', Academy of Management Journal 47(1), 260-272.

Ariss, S. S.: 2003, 'Employee Involvement to Improve Safety in the Workplace', Mid-American Journal of Business 18(2), 9-16.

Ashforth, B. E.: 1994, 'Petty Tyranny in Organizations', Human Relations 47(7), 755-778.

Ayoko, O. B., V. J. Callan and C. E. J. Härtel: 2003, 'Workplace Conflict, Bullying and Counterproductive Behaviors', International Journal of Organizational Analysis 11 14, 283-301.

Bagshaw, M.: 2004, 'Is Diversity Divisive? A Positive Training Approach', Industrial and Commercial Training 36(4), 153-157.

Bennett, R. J. and S. L. Robinson: 2003, 'The Past, Present and Future of Workplace Deviance Research', in J. Greenberg (ed.), Organizational Behavior: The State of the Science, 2nd Edition (Erlbaum, Mahwah, NJ).

Bennett-Alexander, D. and L. P. Hartman: 2007, Employment Law for Business, 5th Edition (McGraw Hill, New York).

Berkowitz, P. M.: 2004, 'New Sarbanes-Oxley Whistleblower Regulations: Their Impact on Business', http:// www.nixonpeabody.com/publications_detail3.asp?Type= $\mathrm{P} \& \mathrm{PAID}=\& 10=756$. (Ed.).

Bernardi, L. M.: 2001, 'Management by Bullying: The Legal Consequences', Canadian Manager: 2, 3:13-14+.

Boyce, T. E. and E. S. Geller: 2001, 'Applied Behavior Analysis and Organizational Safety: The Challenge of Response Maintenance', Journal of Organizational Behavior Management 21(21), 31-60.
Bucklin, B. R., A. M. Alvero, A. M. Dickinson, J. Austin and A. K. Jackson: 2000, 'Industrial-Organizational Psychology and Organizational Behavior Management: An Objective Comparison', Journal of Organizational Behavior Management 20(22), 27-75.

Cleveland, J. N. and M. E. Kerst: 1993, 'Sexual Harassment and Perceptions of Power: An Underarticulated Relationship', Journal of Vocational Behavior 42(1), 49-67.

Cortina, L. M., V. J. Magley, J. H. Williams and R. D. Langhout: 2001, 'Incivility in the Workplace: Incidence and Impact', Journal of Occupational Health Psychology 6(1), 64-80.

Crane, A. and D. Matten: 2004, Business Ethics (Oxford University Press, New York).

Devine, T: 1999, 'The Whistleblower Protection Act of 1989: Foundation for the Modern Law of Employment Dissent', Administrative Law Rev 35, 531-579.

Duffy, M. K., D. C. Ganster and M. Pagon: 2002, 'Social Undermining in the Workplace', Academy of Management Journal 45(42), 331-351.

Einarsen, S.: 1996, Bullying and Harassment at Work: Epidemiological and Psychosocial Aspects (University of Bergen, Bergen).

Einarson, S. and A. Skogstad: 1996, 'Bullying at Work: Epidemiological Findings in Public and Private Organizations', European Journal of Work and Organizational Psychology 5(2), 185-201.

Freeman, R. E.: 1994, 'The Politics of Stakeholder Theory: Some Future Directions', Business Ethics Quarterly 4(4), 409-421.

French, J. and B. H. Raven: 1959, 'The Bases of Social Power', in D. Cartwright (ed.), Studies in Social Power (Institute for Social Research, Ann Arbor, MI).

Gardner, B. A.: (ed.). 1999, Black's Law Dictionary, 7th Edition (MN West Group, St. Paul).

Geller, E. S.: 1996, Psychology of Safety: How to Improve Behaviors and Attitudes on the Job (Chilton Book Company, Rednor, PA).

Giacalone, R. A. and J. Greenberg: 1997, Antisocial Behavior in Organizations (Sage, Thousand Oaks, CA).

Halwani, R.: 2003, 'Care Ethics and Virtue Ethics', Hypatia 18(3), 161-192.

Heames, J. T., M. G. Garvey and D. Treadway: 2006, 'Status Inconsistency: An Antecedent to Bullying Behavior in Groups', International Journal of Human Resource Management 17(2), 348-361.

Held, V.: 1993, Justice and Care: Essential Readings in Feminist Ethics (Westview, Boulder, CO).

Herr, R. S.: 2003, 'Is Confucianism Compatible with Care Ethics?', A Critique. Philosophy East \& West 53(54), 471-489.

Hodson, R., V. Roscigno and S. Lopez: 2006, 'Chaos and the Abuse of Power: Workplace Bullying in 
Organizational and Interactional Context', Work and Occupations 33, 382-416.

Hoel, H. and C. L. Cooper: 2000, Destructive Conflict and Bullying at Work (University of Manchester Institute of Science and Technology (UMIST), Manchester).

Hoel, H., B. Faragher and C. L. Cooper: 2004, 'Bullying is Detrimental to Health, but all Bullying Behaviors are not Necessarily Equally Damaging', British Journal of Guidance and Counseling 32, 438-456.

Hoel, H., C. Rayner and C. L. Cooper: 1999, 'Workplace Bullying', in C. L. Cooper and I. T. Robertson (eds.), International Review of Industrial and Organizational Psychology 14, 195-230.

Hutchinson, M., M. H. Vickers, D. Jackson and L. Wilkes: 2005, “I'm Gonna Do What I Wanna Do." Organizational Change as a Legitimized Vehicle for Bullies', Health Care Management Review 30(4), 331-336.

International Labour Organization: 2000, The Cost of Violence/Stress at Work and the Benefits of a Violence/ Stress Free Working Environment (International Labour Organization, Geneva, Switzerland).

Jehn, K. A., G. B. Northcraft and M. A. Neale: 1999, 'Why Differences Make a Difference: A Study of Diversity, Conflict and Performance in Workgroups', Administrative Science Quarterly 44, 741-764.

Joyce, A.: May 5, 2005, Big Bad Boss Tales: Overbearing Management Styles Are All The Rage, Did We Say Rage? Washington Post, FO1.

Kant, I.: 1981, 'Grounding the Metaphysics of Morals', James W. Ellington (Tr.) (Hackett, Indianapolis, IN).

Keashly, L.: 1998, 'Emotional Abuse in the Workplace: Conceptual and Empirical Issues', Journal of Emotional Abuse 1(1), 85-117.

Keashly, L. and K. Jagatic (eds.): 2003, By Any Other Name: American Perspectives on Workplace Bullying (Taylor and Francis, London).

Kistner, T.: 1997, Mobbing, wo Andere leiden, hort der Spass auf. Frankfurt.

Kivimaki, M., M. Virtanen, M. Vartia, M. Elovainio, J. Vahtera and L. Keltikangas-Jarvinen: 2003, 'Workplace Bullying and the Risk of Cardiovascular Disease and Depression', Occupational and Environmental Medicine 60, 779-83.

LePoidevin, J.: 1996. 'Tackling Workplace Bullies', IRS Employment Review 611, SSS11-SSS13.

Leymann, H. and A. Gustafsson: 1996, 'Mobbing at Work and the Development of Post-Traumatic Stress Disorders', European Journal of Work and Organizational Psychology 5(2), 251-275.

Mack, J. A.: 2005, 'The Law of Bullying: Off the Playground and into the Workplace', Bench \& Bar of Minnesota 62(8), 20-24S.
Maitland, I.: 1989, 'Rights in the Workplace: A Nozickian Argument', Journal of Business Ethics 8(12), 951954.

McCarthy, P.: 1996, 'When the Mask Slips: Inappropriate Coercion in Organisations Undergoing Restructuring', in P. McCarthy, M. Sheehan and W. Wilkie (eds.), Bullying: from Backyard to Boardroom (Millennium Books, Alexandria, Australia), pp. 47-65.

McSween, T. and G. A. Mattews: 2001, 'Maintenance in Safety Behavior Management', Journal of Organizational Behavior Management 21(1), 75-82.

Namie, G.: 2000, U.S. Hostile Workplace Survey 2000. Retrieved at: http://www.bullyinginstitute.org.

Namie, G. and R. Namie: 2000, The Bully at Work: What You Can do to Stop the Hurt and Reclaim Your Dignity on the Job (Sourcebooks Inc, Naperville, IL).

Namie, G. and R. Namie: 2005, Bully Busters: National Coordinators of U.S. State Legislative Initiatives to Stop Workplace Bullying.

Namie, G. and R. Namie: 2006, Workplace Bullying: Introduction to the 'Silent' Epidemic. Workplace Bullying Institute. Available at: http://www. bullyinginstitute.org.

Neuman, J. H. and R. A. Baron: 1998, 'Workplace Violence and Workplace Aggression: Evidence Concerning Specific Forms, Potential Causes, and Preferred Targets', Journal of Management 24(3), 391419.

Nijhof, A. H. J. and M. M. Rietdijk: 1999, 'An A-B-C Analysis of Ethical Organizational Behavior', Journal of Business Ethics 20(1), 39-50.

O'Leary-Kelly, A. M., R.W. Griffin and D. J. Glew: 1996, 'Organization-Motivated Aggression: A Research Framework', Academy of Management Review 21(1), 225-253.

O'Moore, M., E. Seigne, L. McGuire and M. Smith: 1998, 'Victims of Workplace Bullying in Ireland', The Irish Journal of Psychology 19(2/3), 345-357.

Paoli, P. and D. Merllié: 2001, 'Third European Survey on Working Conditions 2000', Office for Official Publications of the European Communities. Luxembourg.

Pelled, L. H.: 1996, 'Demographic Diversity, Conflict, and Work Group Outcomes: An Intervening Process Theory', Organization Science 6, 615-631.

Pryor J. B. and L. F. Fitzgerald: 2003, 'Sexual Harassment Research in the United States', in S. Einarsen, H. Hoel, D. Zapf and C. Cooper (eds.), Bullying and Emotional Abuse in the Workplace: International Perspectives in Research and Practice (Taylor \& Francis, London).

Quine, L.: 1999, 'Workplace Bullying in NHS Community Trust: Staff Questionnaire Survey', British Medical Journal 318, 228-232. 
Rayner, C.: 1997, 'The Incidence of Workplace Bullying', Journal of Community and Applied Social Psychology 7, 199-208.

Rayner, C.: 1999, 'From Research to Implementation: Finding Leverage for Prevention', International Journal of Manpower 20(1/2): 28.

Robinson, S. L. and R. J. Bennett: 1995, 'A Typology of Deviant Workplace Behaviors: A Multidimensional Scaling Study', Academy of Management Journal 38(2), 555-572.

Salin, D.: 2001, 'Prevalence and Forms of Bullying Among Business Professionals: A Comparison of Two Different Strategies for Measuring Bullying', European Journal of Work and Organizational Psychology 10(4), 425-441.

Salin, D.: 2003, 'Ways of Explaining Workplace Bullying: A Review of Enabling, Motivating and Precipitating Structures and Processes in the Work Environment', Human Relations 56(10), 1213-1232.

Schultz, V.: 2003, 'The Sanitized Workplace', Yale Law Journal 112, 2061.

Schumann, P.: 2001, 'A Moral Principles Framework for Human Resource Management Ethics', Human Resource Management Review 11, 93-111.

Sheehan, M.: 1996, 'Case Studies in Organisational Restructuring', in P. McCarthy, M. Sheehan, D. Wilkie (eds.), Bullying: From Backyard to Boardroom (Millennium, Alexandria, VA).

Tracy, S. J., P. Lutgen-Sandvik and J. K. Alberts: 2006, 'Nightmares, Demons, and Slaves: Exploring the Painful Metaphors of Workplace Bullying', Management Communication Quarterly 20(2), 148-185.

UMIST: 2001, Survey of Employee Bullying. Guardian(3 February): 3.

UNISON: 1997, Bullying At Work: Guidelines for UNISON Branches, Stewards and Safety Representatives (UNISON, London).

U.S. Department of Justice, FBI: 2004, 'Workplace Violence: Issues and Response', http://www.fbi.gov/ publications/violence.pdf.

Vandekerckhove, W. and M. S. R. Commers: 2003, 'Downward Workplace Mobbing: A Sign of the Times?', Journal of Business Ethics 45(1), 41-50.

Vartia, M.: 1996, 'The Sources of Bullying - Psychological Work Environment and Organizational Climate', European Journal of Work and Organizational Psychology 5(2), 203-214.

Vartia, M.: 2001, 'Consequences of Workplace Bullying with Respect to the Well-Being of its Targets and the Observers of Bullying', Scandinavian Journal of Work, Environment and Health 27, 63-9.

Werhane, P. H., T. J. Radin and N. E. Bowie: 2004, Employment and Employee Rights (Blackwell Publishing, London).
Wormald, K.: 2005, 'When Your Boss Is a Bully', Office Solutions 22(4), 42. .

Yamada, D. C.: 2000a, 'The Phenomenon of "Workplace Bullying" and the Need for Status-Blind Hostile Work Environment Protection', 88 Georgetown Law Journal 475.

Yamada, D.: 2000b, 'Brainstorming About Workplace Bullying: Potential Litigation Approaches For Representing Abused Employees', Employee Advocate 49, 5152.

Zapf, D., C. Knorz and M. Kulla: 1996, 'On the Relationship Between Mobbing Factors, and Job Content, Social Work Environment, and Health Outcomes', European Journal of Work and Organizational Psychology 5(2), 215-237.

Zogby International.: 2007, U.S. Workplace Bullying Survey. Available at: http://www.workplacebullyinginstitute. org.

Zucker, R.: 2000, Democratic Distributive Justice (Cambridge University Press, New York).

\section{Relevant websites}

http://www.bullybusters.org/.

http://www.bullyinginstitute.org/.

http://www.bullyonline.org/workbully/costs.htm.

http://www.workdoctor.com/definedB.html.

\section{Cases and legislation cites}

Burlington Northern \& Santa Fe Railway Co. v. White (548 U.S. Supreme Court; 2006).

California Labor Code $\$ 3601$.

California Assembly Bill No. 1582-2003.

Civil Rights Act of 1964.

Daniel H. Raess, M.D. vs. Joseph E. Doescher (858 N.E.2d 119; Ind. App).

Food, Drug and Cosmetic Act.

Len Eserhut, v. Steve Heister and Jane Doe Heister (52 Wn. App. 515) Occupational Safety and Health Act 29 U.S.C. $660(\mathrm{c})$.

Palmateer v. International Harvester (85 Ill. 2d 124, 421 N.E. 2d 876, 1981).

Pa. State Police v. Suders (542 U.S. 129; 124 S. Ct.).

Sheets v. Teddy's Frosted Foods (179 Conn. 471 A 2d 386, 1980).

Management, DePaul University, 1E. Jackson Blvd, Chicago, IL 60604, U.S.A. E-mail:hlavan@depaul.edu 